\title{
The asterostomatid echinoid Antillaster from the Paradash Group (Middle Eocene) of the Nakhichevan Region of Azerbaijan
}

\author{
Kenneth J. McNamara ${ }^{1}$ and Oktay H. Melikov ${ }^{2}$ \\ 'Department of Earth and Planetary Sciences, Western Australian Museum, Francis Street, \\ Perth, Western Australia 6000, Australia \\ ${ }^{2}$ Azerbaijan State Oil Academy, 370102 Azadlik pr. 20, Baku, Azerbaijan
}

\begin{abstract}
The asterostomatid echinoid Antillaster has previously been recorded only from the Caribbean region and northeastern South America. Here we report the first occurrence of this genus from outside the Americas, in the Lesser Caucasus, where it has been found in Middle Eocene sediments of the Paradash Group in the Nakhichevan region of Azerbaijan. The material is described as Antillaster bagmanovi sp. nov. It is the earliest known occurrence of the genus. Its presence in the Paratethys, in a region far removed from previous known occurrences, has significant palaeobiogeographic implications. Its disappearance from the Lesser Caucasus, but persistence in the Caribbean, may be linked to the contraction of the Tethys during the Cenozoic.
\end{abstract}

\section{INTRODUCTION}

Eocene sediments in the Nakhichevan region of Azerbaijan have long attracted the attention of many investigators, due to their good exposure and extensive foraminiferal and molluscan fauna. The dating of the predominantly clay-sand facies as being Eocene is based on this rich foraminiferal and molluscan fauna (Azizbekov 1961; Bagmanov 1966, 1980; Paffengoltc 1979). The presence of an Eocene echinoid fauna in the Nakhichevan region remained unknown until 1958 when, in addition to the foraminifers and molluscs from sections in Juga, Daralik, Ilandag and Bilav, M.A. Bagmanov collected a rich fauna of echinoids from the Paradash Group. Unfortunately, this fauna remained unstudied for many years. However, in 1984 Bagmanov kindly passed his echinoid collection over to one of us (O.H.M). During 198587 Melikov, to supplement this collection, collected additional material from Bagmanov's sections. These collections from the Paradash Group have yielded a rich echinoid fauna, comprising 25 species (Melikov in prep.). Current work by Melikov suggests that these species can be assigned to 14 genera in 11 families, and 5 orders. It is interesting that this species richness is in strong contrast to a fauna of equivalent age occurring in sediments in the neighbouring territory of Armenia, a mere 40$50 \mathrm{~km}$ away. Here only six species are known.

One of the more surprising echinoid finds from these sediments were large specimens of Antillaster. The asterostomatid echinoid Antillaster has previously been described only from the Caribbean region and northern South America, specifically from Eocene to Miocene sediments in Venezuela, Cuba, Jamaica, Bonaire, Antigua, Puerto Rico and Mexico (Kier 1984). Here we report the first record of this genus from outside the Caribbean region, in Middle Eocene sediments of the Lesser Caucasus region in Azerbaijan. This provides the earliest record of asterostomatid echinoids in the Paratethys region.

\section{GEOLOGICAL SETTING AND BIOSTRATIGRAPHY}

Middle Eocene sediments are are widespread in the southwestern part of the Nakhichevan region of Azerbaijan, extending to the Arax River, which marks the border with Iran. These sediments are separated by a pronounced unconformity from underlying Triassic sediments. This boundary is marked by a thick basal conglomerate. The Middle Eocene sediments are divided into three groups, which extend through six foraminiferal zones (Figure 1).

\section{Daralik Group}

\section{Lower subgroup}

Along the south-west limb of the Nakhichevan synclinal basin, particularly at Daralik (on the right bank of the Alinjachai River), this basal unit of the Middle Eocene sequence encompasses the Nummulites laevigatus zone and is represented mainly by conglomerates containing a series of isolated packets and lenses of limestones, clay-shale and sandstones. It is characterised by its reddish- 


\begin{tabular}{|c|c|c|c|c|}
\hline \multicolumn{2}{|c|}{$\begin{array}{l}\text { Upper } \\
\text { Eocene }\end{array}$} & $\begin{array}{c}\text { Globerigina corpulenta } \\
\text { zone }\end{array}$ & \multirow{4}{*}{$\begin{array}{c}\text { Paradash } \\
\text { Group }\end{array}$} & \multirow{4}{*}{ 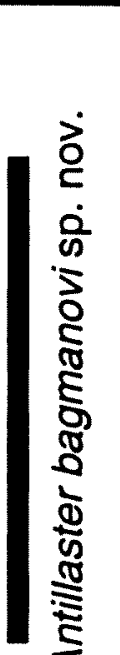 } \\
\hline \multirow{2}{*}{$\begin{array}{l}\boldsymbol{\omega} \\
\subset \\
\Phi\end{array}$} & \multirow{2}{*}{ 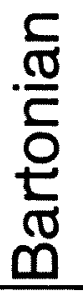 } & $\begin{array}{c}\text { Truncorotaloides rohri } \\
\text { zone }\end{array}$ & & \\
\hline & & $\begin{array}{c}\text { Acarinina rotundomarginata } \\
\text { zone }\end{array}$ & & \\
\hline $\begin{array}{l}0 \\
\text { 山 }\end{array}$ & 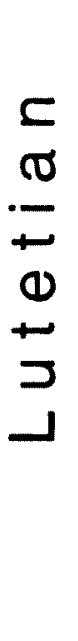 & $\begin{array}{c}\text { Globeriginatheka subconglobata } \\
\text { zone }\end{array}$ & & \\
\hline \multirow{3}{*}{$\begin{array}{l}\frac{0}{0} \\
\overline{0} \\
\frac{1}{\Sigma}\end{array}$} & \multirow{3}{*}{$\begin{array}{l}\mp \\
\square \\
\pm \\
\square \\
\square\end{array}$} & $\begin{array}{c}\text { Nummulites atacicus } \\
\text { zone }\end{array}$ & $\begin{array}{l}\text { Bilav } \\
\text { Group }\end{array}$ & \\
\hline & & $\begin{array}{l}\text { Morozovella aragonensis } \\
\text { zone }\end{array}$ & \multirow{2}{*}{$\begin{array}{l}\text { Daralik } \\
\text { Group }\end{array}$} & \\
\hline & & $\begin{array}{l}\text { Nummulites laevigatus } \\
\text { zone }\end{array}$ & & \\
\hline
\end{tabular}

Figure 1 Biostratigraphic chart showing the foraminiferal zonation, stratigraphic groups and range of Antillaster bagmanovi in the Nakhichevan region of Azerbaijan Republic.

brown colouring. The thickness of the subgroup varies between $5-10 \mathrm{~m}$ to $120-150 \mathrm{~m}$. This subgroup contains abundant Nummulites of Middle Eocene age, notably $N$. laevigatus (Brug.), N. laevigatus var. lantaensis Lerisch (B) and the echinoids Porosoma lamberti Checcia-Rispoli, Triplacidia veronensis Bittner, Echinolampas daralagesensis Poretzkaja, E. blaviensis Cotteau, Echinanthus cf. issyaviensis (Klein) and Cyclaster subquadratus (Desor). The presence of $N$. laevigatus indicates a Lower Lutetian age, foraminiferal zone P10.

\section{Upper subgroup}

This encompasses the Morozovella aragonensis zone. Up the section this predominantly conglomerate subgroup is intermixed with layers of shelly-sandstone, argillites and rarely limestones, containing abundant Nummulites. Within this subgroup in the Julfa region, occur lenses of gypsumised shale and aleurolites, $150 \mathrm{~m}$ thick. These sharply decrease in thickness along both limbs of the Bilav fold. The most common foraminifers in the zone are Nummulites laevigatus (Brug.) and N. uranensis Heim. Other foraminifers include Acarinina bulbrooki Bolli and Globigerina postiloculinoides Chalilov. Acarinina bulbrooki occurs in the Lower Lutetian, P9 and P10. N. uranensis occurs in P10. Echinoids occurring in this upper subgroup are Schizaster (Schizaster) rindensis Poretzkaia, S.(S.) sp. nov., Maretia hoffmani Goldfuss and $M$. sp. nov.

\section{Bilav Group}

This is represented by tuffaceous conglomerate, tuff, tuffite of andesite to andesite-dacite composition and lenses of sandy shale. The total thickness of this group is $875 \mathrm{~m}$. Bagmanov (1966) identified Nummulites laevigatus (Brug) within this group. Highly developed olistolites of very different-sizes is a characteristic feature of this group.

\section{Paradash Group}

Palaeontologically this group is divided into four biostratigraphical zones from the lowest Globigerinatheka subconglobata zone up through the Acarinina rotundomarginata zone, the Truncorotaloides rohri zone to the Globigerina corpulenta zone. The lower three are included within the Middle Eocene, the Globigerina corpulenta zone being Upper Eocene. 
Globigerinatheka subconglobata zone

This overlies the tuffaceous conglomerate of the Bilava Group and is represented in its lower part by repeated beds of argillites, sandstones and clay/ shales, having a total thickness of $126 \mathrm{~m}$. These rocks are overlain by $70 \mathrm{~m}$ of repeated beds of dark red clay/shale, argillites and subordinate interbedded sandstones. Over these lie a $100 \mathrm{~m}$ thick sequence of greyish clay. This lowest subgroup is capped by a sequence of repeated sandstone and clay/shale $55 \mathrm{~m}$ thick, with a $4 \mathrm{~m}$ thick conglomerate at its base. The beds of this subgroup extend along the southern limb of Ilandag Mountain.

Clay/shale of all packets contain a foraminiferal assemblage containing Acarinina bulbrooki (Bolli), which ranges from P9-P10, A. punctocarinata Fleish, Morozovella spinulosa Cushman, which ranges from P10-P14, Globigerina boweri Bolli and Nummulites laevigatus Brug., which occurs in P10, and an echinoid fauna of Schizaster (Schizaster) rindensis Poretzkaia, Linthia (Linthia) soudanensis Bather, Gualtieria (Gualtieria) damesi Koch, Eupatagus (Eupatagus) formosus Loriol and Maretia hoffmani Goldfuss. G. subconglobata occurs in P11. Thus this sequence is probably near the Lower-Middle Lutetian boundary.

\section{Acarinina rotundomarginata zone}

This is represented by repeated beds of clay, sandstone and argillites having a total thickness of $391 \mathrm{~m}$. Foraminifers present include Subbotina frontosa Subbotina (P11-P14), Acarinina vievensis Morozova, Morozovella lehneri Cushman (P12-P13), Hantkenina alabamensis Cushman (P12), Nummulites acutus (Sowerby) and N. striatus (Brug.). The species of echinoids recovered from this zone are: Antillaster sp. nov., Gualtieria (Gualtieria) damesi Koch, Triplacidia veronensis Bittner, Schizaster (Schizaster) sp. nov., Schizaster (Paraster) rimosus L. Agassiz, Conoclypus conoideus Leske, and C. leymeriei Cotteau. The planktic forams indicate a foraminiferal zone of P12, which is Upper Lutetian to early Lower Bartonian.

\section{Truncorotaloides rohri zone}

This consists of red-brownish $(43 \mathrm{~m})$ and greyish $(25 \mathrm{~m})$ clay with interbeds of sandstones containing nummulites. This zone is characterised by the presence of numerous Truncorotaloides rohri Brönnimann and Bermudez (P11-P14), Globigerina incretacea Chalilov, $G$. praebulloides Blay., Nummulites brongniarti D'Archiac and Haime (P12P14), N. perforatus (Mont.)(P12-P14), N. striatus (Breys.). Echinoids occurring in this zone are Conoclypus conoideus Leske and Antillaster sp. nov. The foraminifers indicate a possible Upper Bartonian age.
Globigerina corpulenta zone

Sediments within this zone consist of repeated beds of nummulitic sandstones, clays and conglomerates, $50 \mathrm{~m}$ thick. Foraminifers present include Nummulites striatus (Brug.), N. brongniarti D'Archiac and Haime, N. paradashensis Mamedov, $N$. fabiani Prever, $N$. rectus Currey. $N$. brongniarti is Bartonian, and N. fabiani uppermost Bartonian to Lower Priabonian.

The Paradash Group would therefore seem to range from near the Lower-Middle Lutian boundary to the Upper Bartonian or earliest Pribonian. The sequence at Daralik probably occupies the entire Middle Eocene, possibly extending into the lowest part of the Upper Eocene.

\section{SYSTEMATIC PALAEONTOLOGY}

\section{Order Spatangoida Claus, 1876}

\section{Family Asterostomatidae Pictet, 1857}

\section{Genus Antillaster Lambert, 1909}

\section{Type species}

Asterostoma cubensis Cotteau, 1871; by original designation of Lambert, 1909, p. 103.

\section{Diagnosis}

Test large, low to high; apical system ethmolytic with 3 or 4 genital pores; petals long, wide, open, flush with test, or very slightly depressed; anterior ambulacrum with small pores, in slight groove or flush with test; some plates occluded at ends of petals; peristome large; periproct large, inframarginal; tubercles small, no fascioles; plastron mesamphisternous with large labrum, narrow sternal plates, large episternal plates; in some species first plate in interambulacrum 1 followed by single plate (after Kier 1984:131).

\section{Remarks}

Species of Antillaster are particularly characterised by their very large test size, typically reaching in excess of $100 \mathrm{~mm}$ test length, but sometimes to over $150 \mathrm{~mm}$. Antillaster lacks any evidence of fascioles, hence its assignment to the Asterostomatidae. Antillaster bears a superficial resemblance to the brissid Pharaonaster, which is known from the Eocene of North Africa (Roman and Strougo 1994). However, Antillaster can be distinguished by its much larger test size and absence of fascioles; peripetalous and subanal fascioles are present in Pharaonaster. Another superficially similar form is Hypsopatagus, which is known from the Eocene to Oligocene of parts of Europe, Asia and North America. However, unlike Antillaster it has a peripetalous fasciole; is smaller; and has closed, rather than open, petals. On account of its large size, 
absence of fascioles, distally open petals that are almost flush with the surface of the test, the form described herein from Azerbaijan is considered to be a species of Antillaster.

\section{Antillaster bagmanovi sp. nov.}

Figures 2-7

\section{Diagnosis}

Species of Antillaster with very slightly sunken petals; anteriorly divergent petals with very narrow interporiferous zone; peristome sunken; ambulacrum III deeply sunken orally.

\section{Material}

Holotype WAM 99.428, from Daralik, Nakhichevan region of Azerbaijan Republic; paratypes WAM 99.429 and 99.432 from the same horizon and locality; other specimens WAM 99.427, 99.430, 99.431 and 99.433 from the same horizon and locality. All specimens collected by $\mathrm{O} . \mathrm{H}$. Melikov from the Acarinina rotundamarginata zone,
Paradash Group (Middle Eocene - Upper Lutetian to early Lower Bartonian).

\section{Etymology}

Named in honour of palaeontologist M. A. Bagmanov.

\section{Description}

Test very large, reaching up to $154 \mathrm{~mm} \mathrm{TL}$; cupola-shaped, with apex anterior of centre; height about $50 \% \mathrm{TL}$; test longer than wide, ranging between $90-94 \% \mathrm{TL}$. Aboral surface declines more steeply anteriorly; ambitus broadly rounded. Shallow anterior notch present. Apical system anteriorly eccentric, $41-46 \% \mathrm{TL}$ from anterior ambitus; ethmolytic, with four genital pores, madreporite extending posteriorly the same distance again as the distance between the anterior and posterior pairs of genital pores.

Ambulacrum III very slightly depressed aborally; pore pairs very small. Anterior petals slightly flexuous, curving anteriorly distally; very slightly

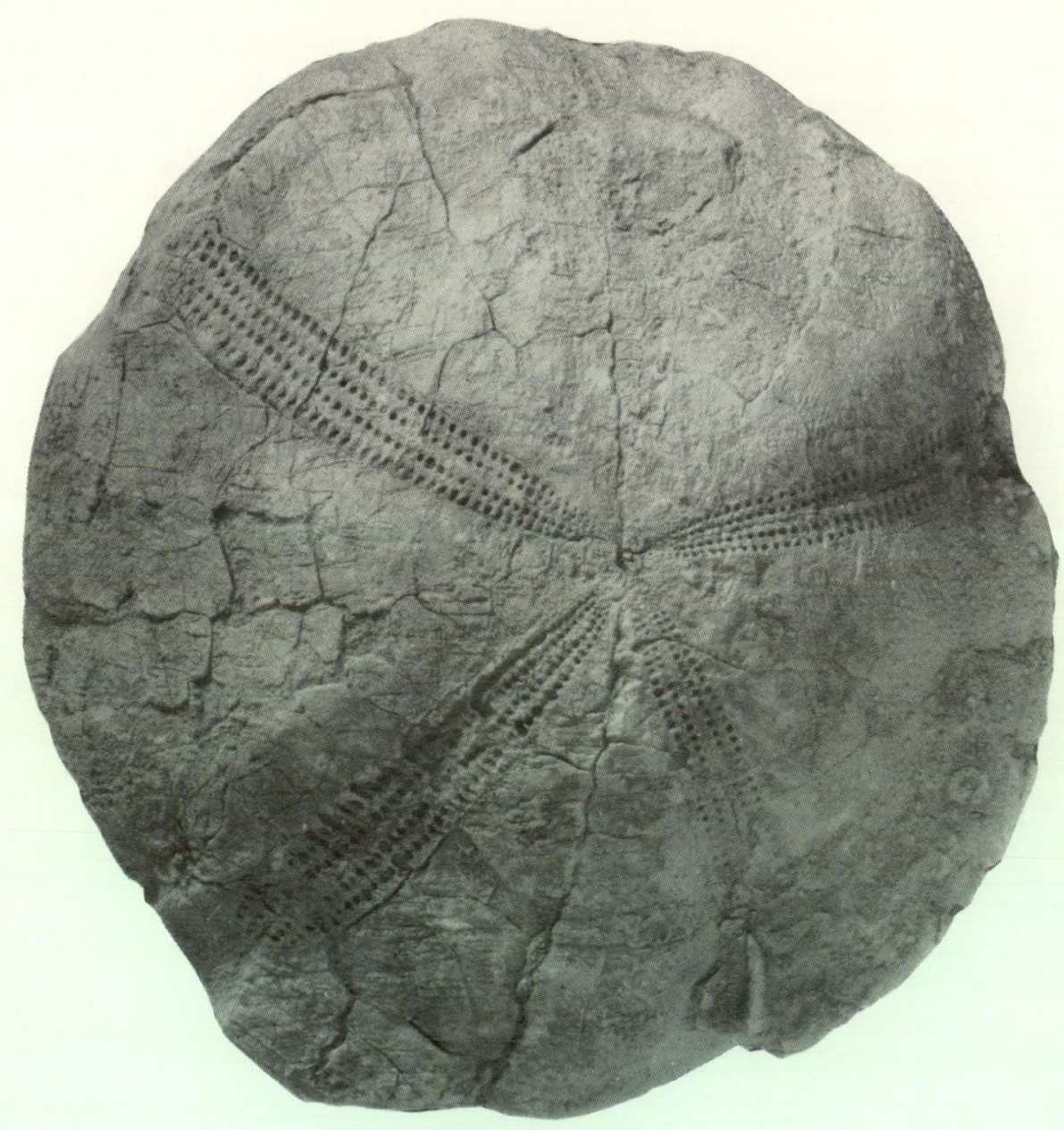

Figure 2 Antillaster bagmanovi sp. nov. WAM 99.428; holotype, aboral view; from Paradash Group (Middle Eocene), Daralik, Nakhichevan region of Azerbaijan Republic; x1. 

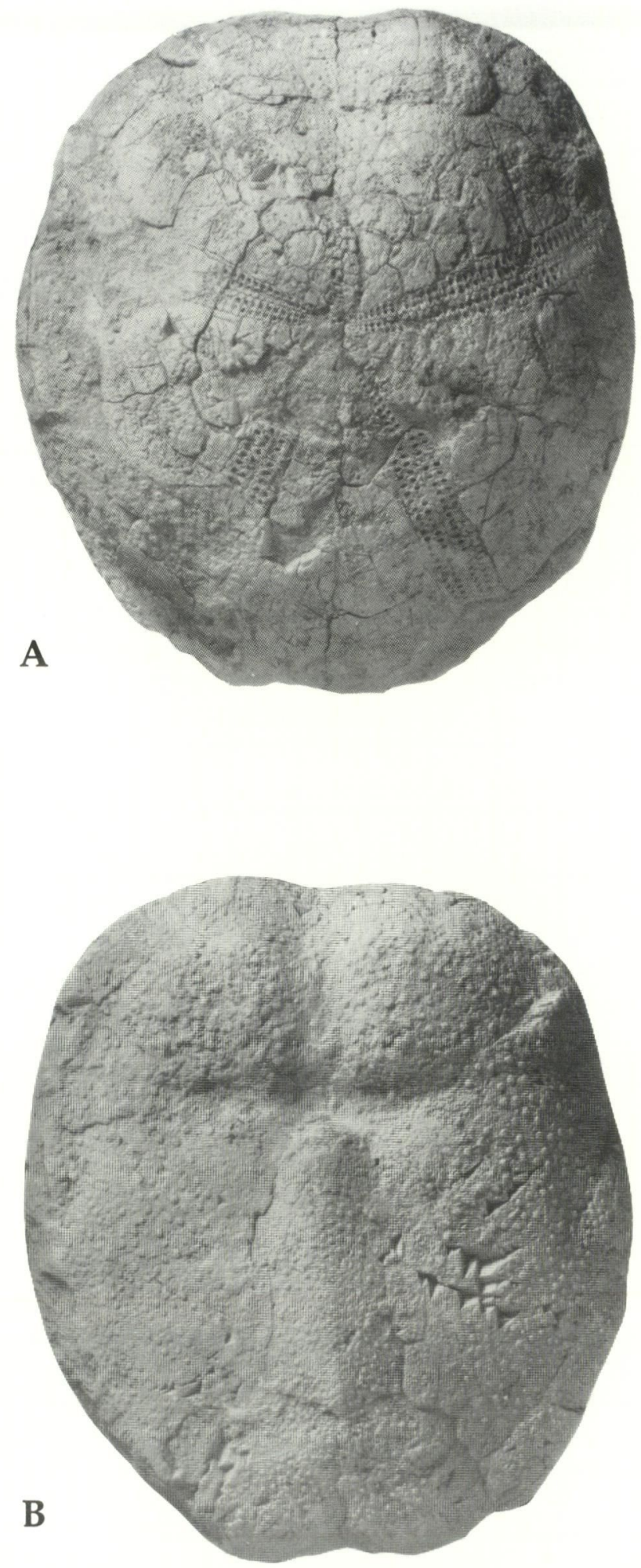

Figure 3 Antillaster bagmanovi sp. nov. WAM 99.429; paratype, A, aboral view, B, adoral view; from Paradash Group (Middle Eocene), Daralik, Nakhichevan region of Azerbaijan Republic; $x 1$.

sunken; width $8-9 \% \mathrm{TL}$; diverging anteriorly at about $140^{\circ}$; long, $43-48 \% \mathrm{TL}$, extending to the ambitus; distally open; with up to 46 pore pairs in each row; inner pores circular, outer pores slightly elongate, not conjugate; interporiferous zone narrow, being less than width of pore pairs in smallest specimen (TL $89.5 \mathrm{~mm}$ ) to slightly greater in largest specimen. Posterior petals also very slightly sunken; straight; slightly longer than anterior, being $46-52 \% \mathrm{TL}$; with up to 51 pore pairs in each row; nature of pore pairs and width of interporiferous zone same as in anterior petals; slightly wider than anterior petals, being $8-10 \% \mathrm{TL}$. Terminal ambulacrum plates of petals sometimes occluded.

Aboral tubercles relatively sparsely distributed; range in diameter from 0.8 to $1.6 \mathrm{~mm}$ in largest specimen. Set in a dense field of miliary tubercles. Fascioles absent.

Oral surface with moderately convex interambulacral areas and sunken ambulacra. These are very weakly sunken ambitally, increasing in depth to relatively deeply sunken peristome. Ambulacrum III deeply sunken throughout. Peristome width $11 \%$ TL; moderately crescentic; posterior of peristome situated $30-35 \%$ TL from anterior ambitus. Labrum strongly arcuate anteriorly. Plastron length $24-34 \% \mathrm{TL}$, being relatively longer in smaller specimens; width 17$21 \% \mathrm{TL}$; gently convex. Episternal plates about half the length of sternal plates, but episternal and preanal plates combined are longer than sternal plates. Periproct inframarginal, transversely oval, width 12-13\%TL. Adoral tuberculation slightly more dense than on aboral surface; primary tubercles of more even diameter; up to $1.5 \mathrm{~mm}$; slightly smaller on plastron than on lateral interambulacra; set in field of dense miliary tubercles.

\section{Ontogenetic variation}

While the partially weathered and usually somewhat crushed nature of the specimens precludes any detailed ontogenetic assessment of the species, some differences are apparent between the smallest specimen (WAM 99.429, test length 89 $\mathrm{mm})$, compared with the other, larger, individuals (125 to $154 \mathrm{~mm}$ ). The plastron in the smaller individual is distinctly narrower, with a length to width ratio of $1: 1.77$, compared with $1: 1.27-1: 1.40$ $(n=5)$ in the larger ones. Furthermore, the petals are slighty more sunken in larger individuals, as is the anterior ambulacrum on the oral surface. The interporiferous zone increases slightly in relative width during ontogeny, being slightly narrower than the width of the pore pairs in the smallest specimen, becoming wider than pore pair width in the largest specimens.

\section{Remarks}

Kier (1984) considered that there were two species groups of Antillaster present in the Caribbean region. One he characterised by its possession of a 


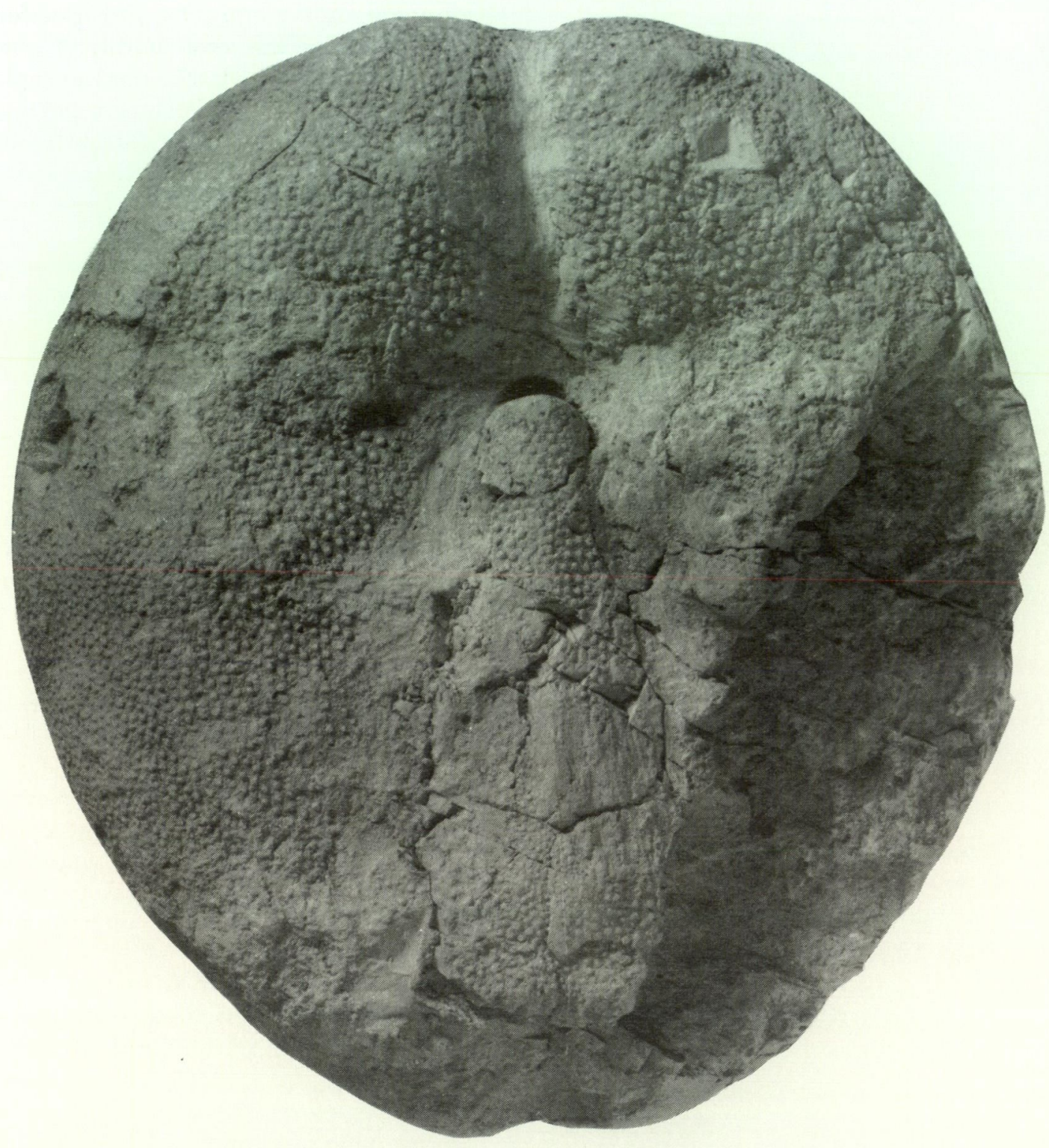

Figure 4 Antillaster bagmanovi sp. nov. WAM 99.432; paratype, adoral view; from Paradash Group (Middle Eocene), Daralik, Nakhichevan region of Azerbaijan Republic; x1.

large, very high, steep-sided test, with a flat ventral surface and very wide petals. Species within this group range in age from the Oligocene to Miocene. Kier characterised the second group (which comprises species ranging in age from Eocene to Miocene) by the possession of relatively lower, more elongate test, more rounded ventral surface and narrower petals. In its possession of narrow petals and relatively lower test with more rounded ventral surface, $A$. bagmanovi resembles the second, probably more primitive, group.

Antillaster bagmanovi can be readily distinguished from all other described species of Antillaster by virtue of its slightly sunken petals that have a very narrow interporiferous zone, and orally possessing a relatively deeply sunken ambulacrum III. The only other known Eocene species of Antillaster are A. arnoldi Clark in Arnold and Clark, 1927 from the
Eocene of Jamaica and A. albeari Kier, 1984 from the Middle to Late Eocene of Cuba. The apical system is less anteriorly situated in A. bagmanovi than in these two species. Moreover, it has sunken petals that are more anteriorly divergent and narrower interporiferous zone. Although sharing slightly sunken petals, $A$. bagmanovi can be distinguished from $A$. albeari by possessing more anteriorly divergent petals, very much narrower anterior and posterior petals and interporiferous zone, more vaulted test and deeper anterior ambulacrum on the oral surface.

Like A. elegans Jackson, 1922 from the Miocene of Puerto Rico, A. bagmanovi has an apical system in a similar relative position, a little anterior of central, and slightly anteriorly divergent petals. However, the Azerbaijan species has slightly sunken petals, narrower interporiferous zone, deeper anterior 


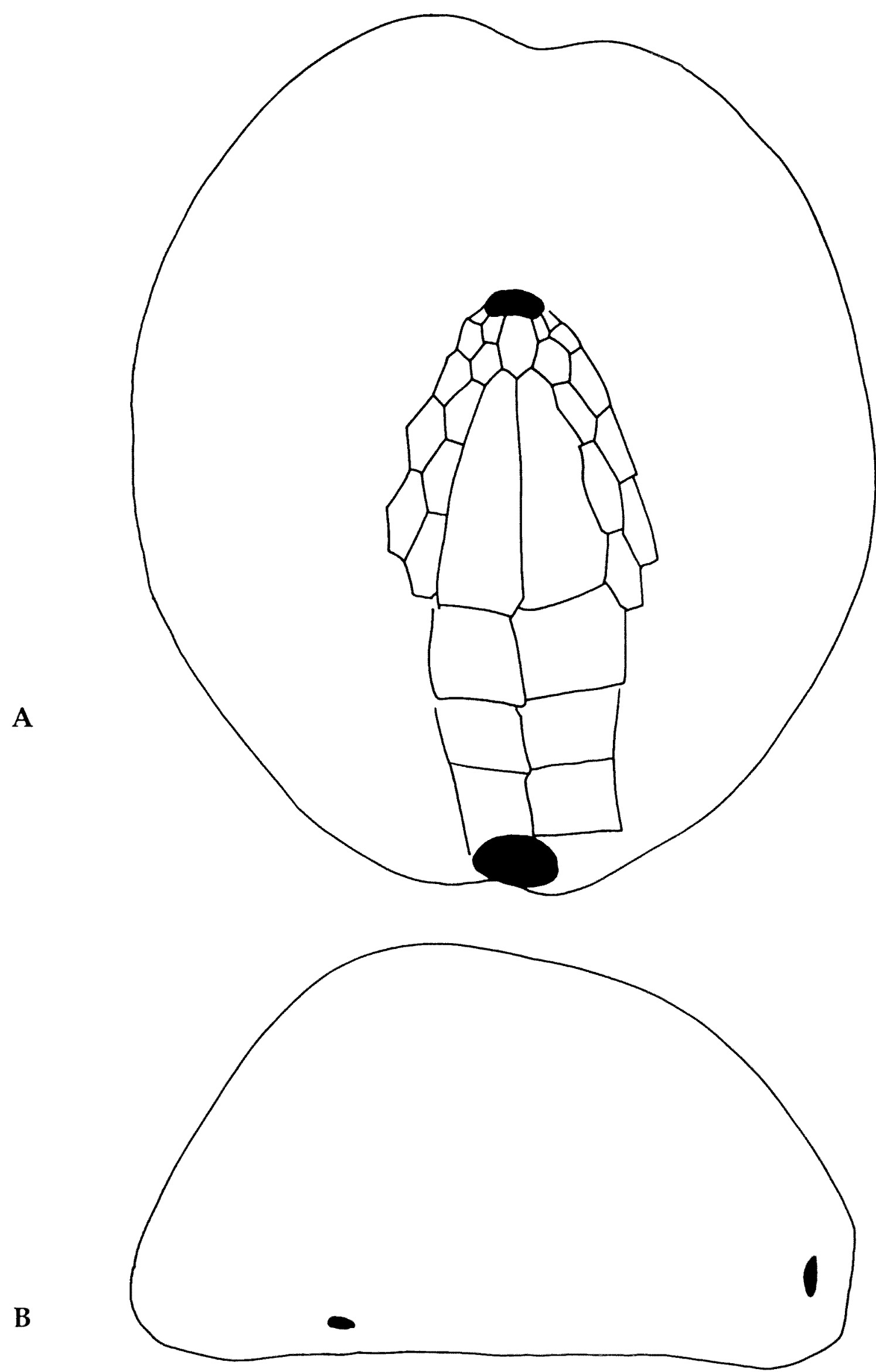

Figure 5 Antillaster bagmanovi sp. nov. WAM 99.432; paratype, A, partial adoral plating, B, lateral profile; from Paradash Group (Middle Eocene), Daralik, Nakhichevan region of Azerbaijan Republic; x0.9. 


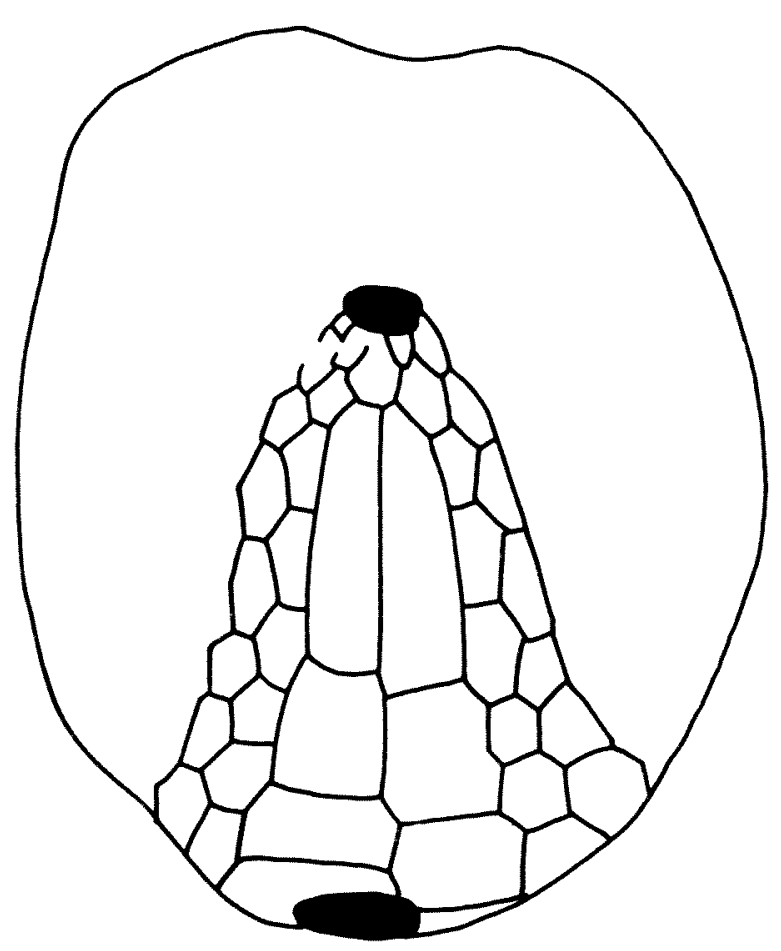

Figure 6 Antillaster bagmanovi sp. nov. WAM 99.429; paratype, partial adoral plating; from Paradash Group (Middle Eocene), Daralik, Nakhichevan region of Azerbaijan Republic; $\mathrm{x} 1$.

ambulacrum orally and narrower labrum. Another species to possess a narrow interporiferous zone is A. fernandezi (Sanchez Roig, 1952) from the Oligocene-Miocene of Cuba (Kier 1984). However, A. bagmanovi has narrower petals that are anteriorly more divergent, a less vaulted test and four, not three, gonopores.

Antillaster bagmanovi can also be distinguished from A. vaughani (Jackson, 1922) from the Oligocene-Miocene of Antigua, Mexico and Cuba (Kier 1984) by its narrower interporiferous zone, sunken petals, deeper anterior ambulacrum orally, narrower peristome and narrower plastron. $A$. sanchezi Lambert in Lambert and Thiéry, 1924 from the Early - Middle Miocene of Cuba (Kier 1984) has, like $A$. bagmanovi, a very narrow interporiferous zone and slightly sunken petals, but the Azerbaijan species has a more central apical system, more anteriorly divergent petals that are not so parallel-sided, and a deeper anterior ambulacrum orally.

\section{BIOGEOGRAPHIC IMPLICATIONS}

The highly disjunct Eocene populations of Antillaster, with nine Eocene to Miocene species in the Caribbean and one Middle Eocene record in the Lesser Caucasus, suggests an originally widespread distribution as far east as the Eastern Paratheys that contracted rapidly to the west in the Oligocene. Whether Antillaster originated in the west or the eastern parts of the orginal range is hard to establish. Evidence from other echinoids indicates that up until the Early Oligocene there was a relatively free exchange of taxa across the Atlantic Ocean, mainly in a westerly direction. For example, Clypeaster appeared earlier in the Tethyan region than in the Caribbean (Ali 1983). Likewise Echinolampas first appeared in the Mediterranean region during the Late Paleocene, but did not appear in the Caribbean region until the Middle Eocene (Roman 1977). Similarly Rhyncholampas first appeared in the Caribbean at this time, although it is found in the Early Eocene in France (Roman 1977). Comparable east to west migrations are shown by Eupatagus (Roman 1970) and Maretia (Roman 1977). Perhaps of more interest than the likelihood of Antillaster forming part of this east to west migration of faunal elements in the Middle Eocene, is the fact that it disappeared from the eastern part of its range so soon after. This may be a function of its mode of life. Kier (1984) suggests that, like living asterostomatids, Antillaster probably lived on the top of the substrate, lacking features associated with a burrowing mode of life, and in relatively deep water, perhaps up to $800 \mathrm{~m}$ deep, like living members of the family. Its disappearance from the Lesser Caucasus may have been associated with a shallowing of the sea as Tethys contracted through the Cenozoic and a separation of the deep basins of the Eastern Paratethys from deeper basins to the west.

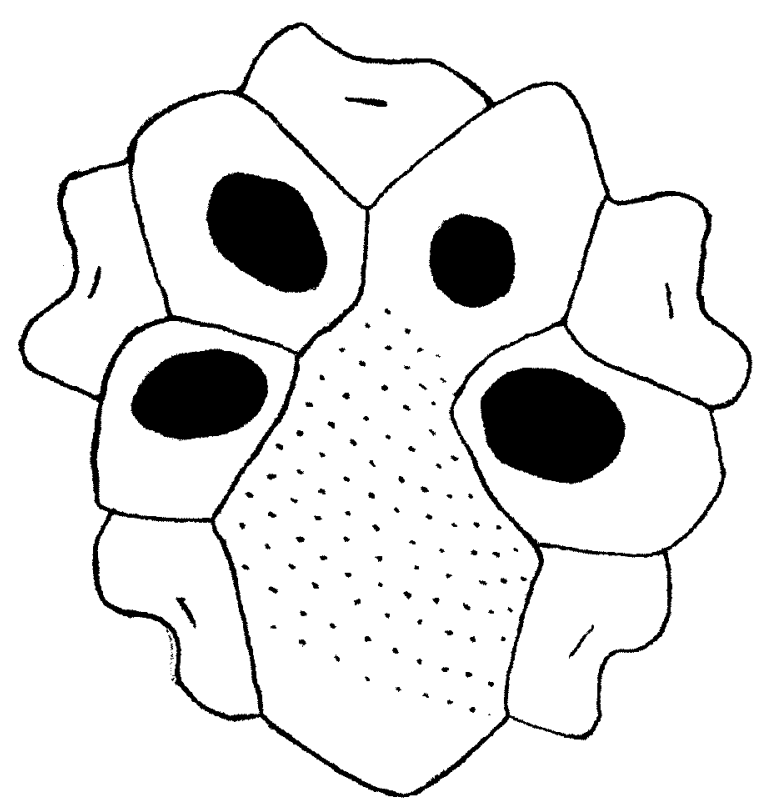

Figure 7 Antillaster bagmanovi sp. nov. WAM 99.431; paratype, apical system plating; from Paradash Group (Middle Eocene), Daralik, Nakhichevan region of Azerbaijan Republic; $\times 15$. 


\section{ACKNOWLEDGEMENTS}

We thank Dr Kevin Kelly, Director of Azerbaijan Relief International, for his assistance; Vasif Melikov for helping with computer services; Dr Andrew Smith for his constructive comments on the manuscript; Dr Stefan Rivets for assistance with foraminiferal biostratigraphy; Kris Brimmell for photography and Danielle West for help with the line drawings.

\section{REFERENCES}

Ali, M.S.M. (1983). The paleogeographic distribution of Clypeaster (Echinoidea) during the Cenozoic Era. Neues Jahrbuch für Geologie und Paläontologie, Monatshefte 1983: 449-464.

Arnold, B.W. and Clark, H.L. (1927). Jamaican fossil Echini, with descriptions of new species of Cainozoic Echinoidea by H.L.Hawkins. Memoirs of the Museum of Comparative Zoology (Harvard) 50: 1-84.

Azizbekov, S.A. (1961). Geology of Nakhichevan ASSR. Gostoptechizdat, Moskow. [In Russian]

Bagmanov, M.A. (1966). Large foraminifers and mollusc fauna of Eocene sediments of Lesser Caucasus. AS of Azerbaijan, Baku. [In Russian]

Bagmanov, M.A. (1980). Paleogene stratigraphy scale. Elm, Baku.

Claus, C. (1876). Grundzüge der Zoologie. 3rd ed. Vol.1. Marburg and Leipzig.

Cotteau, G.H. (1871). II: Notice sur le genre Asterostoma. Société Géologique de France, Memoire (2) 9: 177-184.
Jackson, R.T. (1922). Fossil Echini of the West Indies. Contributions to the Geology and Paleontology of the West Indies 306: 1-103.

Kier, P.M. (1984). Fossil spatangoid echinoids of Cuba. Smithsonian Contributions to Paleobiology 55: 1-336.

Lambert, J. (1909). Description des Echinides fossiles des terrains miocéniques de la Sardaigne. Mémoires de la Société Paléontologique Suisse 35: 74-142.

Lambert, J. and Thiéry, P. (1924). Essaie de Nomenclature Raisonnée des Echinides. Chaumont, Librairie L. Ferriere.

Paffengoltc, K.N. (1979). Paleogene of the Lesser Caucasus. Nedra, Leningrad. [In Russian]

Pictet, F.J. (1857). Traité de Paléontologie, ou, Histoire naturelle des animaux fossiles consideree dans leur rapports zoologiques et geologiques. 2nd Ed, vol. 4, J.-B. Bailliere, Paris.

Roman, J. (1970). Echinides cretaces et éocenes du BasCongo et de cabinda (Côte occidentale d'Afrique). Annales du Museum royale Afrique central, Terouren 68 : $67-76$

Roman, J. (1977). Biogéographie d'un groupe d'Echinides Cenozoiques (Echinolampas et ses sous-genres Conolampas et Hypsoclypus). Geobios 10: 337-349.

Roman, J. and Strougo, A. (1994). Echinoides du Libyen (Eocene Inferieur) d'Egypte. Revue de Paléobiologie 13: 29-57.

Sanchez Roig, M. (1952). Nuevos generos y especies de Equinoideos fosiles Cubanos. Torreia 17: 1-18.

Manuscript received 31 October 2000; accepted 30 November 2001. 